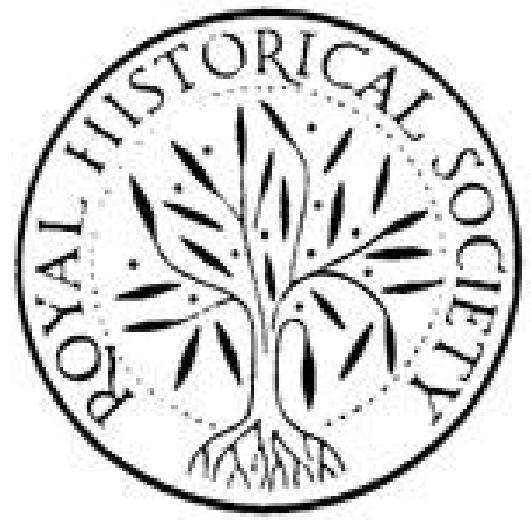

St Procop of Bohemia: A Legend of the Eleventh Century

Author(s): A. H. Wratislaw

Source: Transactions of the Royal Historical Society, Vol. 4 (1876), pp. 439-448

Published by: Cambridge University Press on behalf of the Royal Historical Society Stable URL: http://www.jstor.org/stable/3677929

Accessed: 27-06-2016 14:56 UTC

Your use of the JSTOR archive indicates your acceptance of the Terms \& Conditions of Use, available at

http://about.jstor.org/terms

JSTOR is a not-for-profit service that helps scholars, researchers, and students discover, use, and build upon a wide range of content in a trusted digital archive. We use information technology and tools to increase productivity and facilitate new forms of scholarship. For more information about JSTOR, please contact support@jstor.org.

Cambridge University Press, Royal Historical Society are collaborating with JSTOR to digitize, preserve and extend access to Transactions of the Royal Historical Society 


\section{ST PROCOP OF BOHEMIA: A LEGEND OF THE ELEVENTH CENTURY.}

By the Rev. A. H. WRATISLAW,

Fellow of the Royal Historical Society.

THE great Hussite movement at the commencement of the fifteenth century has never yet been satisfactorily accounted for. Even Palacky, writing under the strict and vexatious censorship of the press at Vienna, has been unable to display in their fulness the various forces which then acted in the same or in parallel directions, and produced that tremendous explosion which shook the Church of Rome to its foundations, and placed the four millions of Bohemian or Czeskish Slavonians for a time, both morally and intellectually, at the head of the nations of Europe. That movement was at once national, intellectual, literary, religious, and also historical ; that is to say, one of the forces which tended to produce it was traditional, and arose from the fact that Bohemia was originally converted by Greek missionaries, possessed a Slavonic ritual of its own, and permitted the use of the chalice to the laity. Hence the surname of the ever-victorious, though eventually totally blind, leader of the Hussites, ZISKA z KALICHU, "Ziska * of the Chalice," the chalice which was borne on the banners of the Hussite armies, and is even now the only ornament allowed in the simple Protestant chapels thinly scattered through the north of Bohemia.

The legend of St Procop, scenes from which are to be found depicted or sculptured by the wayside in various parts of Bohemia, exhibits very strongly the resistance made to the introduction of the Roman ritual to the exclusion of the Græco-Slavonic one. It is also in itself a curious legend, but,

\footnotetext{
* It is not generally known that Ziska is merely an abbreviation of Sigismund.
} 
as might be expected in the case of a saint who interfered actively after death in opposition to the Church of Rome, it is not to be found in such works as Alban Butler's "Lives of the Saints." It occurs in a poetical form in a manuscript of the first half of the fourteenth century, but corrupted rhymes and omitted lines indicate that the composition itself must be considerably older. It has been twice printed this century in Bohemia.

The writer commences by an address to old and young to listen to what he is about to tell them of St Procop, "who was born in Bohemia, successfully extended his order, faithfully fulfilled the holy law, and wrought great miracles." The holy Procop, he continues, was of a Slavonic family in the village of Chotun, not far from Böhmisch Brod. His parents were an old farmer and his wife, who, according to Solomon's wish, were neither over rich nor over poor, but occupied in every respect a middle station. They were God-fearing people, and brought their son up in such a manner that he was soon remarkable for his virtues amongst his equals. Seeing his excellences and the bent of his mind, they sent him to Vyssegrad (High-castle), near Prague, to a distinguished teacher, under whom Slavonic learning and literature were flourishing. Procop paid especial attention to the study of the Scriptures, in which he made such progress that all the teachers marvelled thereat, and remarked upon it among themselves. He was never idle, and never devoted any time to amusement, but was always engaged either in prayer or study, and was "as meek and quiet as if he had been a monk." The canons began to take notice of him, and on account of his humility, made him a priest, and elected him a canon of St Peter's, and they would have elected him their provost, had he not, in order to avoid the snares of the world, refused to accept the position.

Meanwhile, he met with a virtuous old Benedictine monk, and requested him to admit him into his order. The monk at first dissuaded him from giving up the prospects before him in the Church in Bohemia, but eventually consented to 
admit him. Procop then adopted a hermit's life in the neighbourhood of his native district, and finally settled in a forest near the river Sazava, about ten English miles from Kourim. Here he found a rock, on which he proposed to dwell, preoccupied by devils. Undaunted by this, he proceeded to clear away the forest around, and built a chapel in honour of the Virgin Mary. For many years he remained here unknown to all men, but, as a city upon a hill cannot be hid, neither can a fire be under a bushel, so did not God allow him to remain unknown all his days.

A prince named Oldrich (Odalric, Ulric), after a discussion with his attendants as to where they should hunt, determined upon doing so in the hilly neighbourhood of the Sazava. In the course of the hunt, the prince was left entirely alone, and a marvellously beautiful and well-fatted stag appeared before him. Oldrich pursued it, crossbow in hand, and it gradually retired before him, always just keeping out of range, till it reached the rock on which Procop was at work felling an oak. It sprang behind Procop, and turning its antlers towards him, displayed a cross between them.

\footnotetext{
"Seeing that beast of wondrous race, And the monk so meek of face,"
}

Prince Oldrich threw down his crossbow, and pulled up his horse. He then proceeded to question the monk, asking him who he was and what he was doing there. The monk replied that he was a sinner named Procop, living in that hermitage under the rule of St Benedict. Oldrich dismounted, and begged him to hear his confession, which Procop did, and assigned him a penance. After this, the prince requested him to give him something to drink, as he was heated with his long chase. Procop replied that he had no other drink save the water which he drank himself. Taking a drinkingcup, he sighed from his heart, blessed the water with his hand, gave it to the prince, and bade him drink. On drinking, the prince was astonished at finding such excellent wine in so lonely a spot, and said that he had been in many lands, 59 
but had never drunk better wine. Struck by these miracles, he bade Procop collect more brethren about him, for it was his intention to found and endow a convent there, which at Procop's recommendation he determined to dedicate to St John the Baptist. Oldrich took counsel with his lords and esquires, assembled workmen, and had the building erected with all possible speed, and Procop, against his will, was chosen abbot. This happened in the year of our Lord 1009, and in the reign of the Emperor Henry II.

Procop exercised all virtues and all hospitality as abbot, and people crowded to him, " as chickens to a hen," from all quarters. Various miracles of his are related. A person named Menna, who desired to see him, found himself unable to cross the Sazava, all the boats being moored at the other side. Suddenly up came Procop and the brethren, chanting and praising God. Menna prayed that for the merits of Procop God would grant him the means of crossing the water. In a moment a boat released itself from its fastenings, came to him, and conveyed him across. Procop refused to accept the credit of this occurrence, and referred his brethren to the Scriptures, in which the power of true faith, if only as a grain of mustard seed, is exhibited.

Another miracle, given at considerable length in the poem, is the casting out of a devil, which flew up to the church top, but eventually fell down, and burst into four pieces.

Another set of devils complained bitterly that a Bohemian was now set over them, and that they would have to leave their comfortable residence, where Procop and his brethren had established themselves. Procop, overhearing what they said, made himself a whip, put on his priestly robes, went into the cave where they dwelt, and drove them away.

Next is related the restoration of a blind woman to sight. But just as the reverence for Procop was at its height, Prince Oldrich died without completing the convent as he had intended. His successor was his son Bretislaw, who, being informed that Procop had first been a hermit, and then his father's confessor, and that his father had made him many 
promises, in particular engaging to build him a convent, but had died before he had been able fully to carry out his intentions, proceeded to ask the advice of his councillors, who urged him to finish what his father had begun. He went to Procop, took him by the hand, commended himself to his prayers, confessed to him, addressed him as "Holy Father," and confirmed him in all possessions and privileges as abbot. Procop humbly besought him not to lay so great a burthen upon him, but both the prince, Severus, Bishop of Moravia, and all present, insisted on his holding the dignity and accepting the responsibility.

It happened that one of the brethren, who had a particularly fine voice, distinguished himself in chanting the mass, till many people said that he did so "as beautifully as an angel from heaven." Procop, hearing that he was priding himself on this account, rebuked and cautioned him before the assembled brethren.

\footnotetext{
"And that he fear henceforth might have, An ass's penance they him gave."
}

Procop's miracles in healing the sick were numerous; in fact, the author of the poem says that they were without number. Finally a leper came to him, whom he entertained for a week, and when the man wished to take leave and return home, Procop-having given away everything else that he had - begged him to stay three days more, till he himself should be buried, and then he should have his gown to depart with.

Procop was informed of his approaching death by Divine revelation two days before it happened. He communicated the intelligence to two of his friends, Vitos his sister's, and Jimram his brother's, son, and also informed them that endeavours would be made to drive them from their convent by calumny, and that they would be compelled to seek refuge in a foreign land, where they would remain six years. $\mathrm{He}$ exhorted them to unity and love among themselves, and told them the names both of the prince who would persecute them, and of the one who would restore them to their convent. His 
death took place after two days' struggle with the devil, in the year of our Lord 1055, and his funeral ceremony was performed by Severus, Bishop of Prague. His gown was given to the leper above mentioned, and in a moment he was healed, and his flesh became "as the flesh of a little child." The same person, who appears to have been also blind, desiring to see the body of Procop before it was put into the earth, was temporarily restored to sight for the purpose, but the cure was not permanent, as he was a professional beggar, with a great disinclination for work.

Procop's personal appearance is thus described: " He was a man of lofty stature, broad shouldered, strong boned, and full bodied. His head was large, his complexion fair, and beard black. His hair was blackish, and his expression bright and cheerful. His address was kindly, and his heart entirely free from guile."

After his death the brethren took counsel together, and elected the priest Vitos as their abbot. This man had been "the friend of his own soul, and was a person free from all wickedness, a wise man and full of grace." He refused the post, but was compelled by the brethren and the Bishop of Prague to accept it. But in spite of all his excellences, misfortune came upon the brethren, which is thus related by the writer:

"When Bretislaw, good prince, is gone, Ungracious Zbyhnew mounts the throne, Who little holds this convent dear, But lends to calumnies his ear. 'Twas thus the faithless work they plied, Thus to the prince they falsely cried :

' $O$ prince, there are Slavonians here, Another scripture they revere, And divination practise still ;Let them not, prince, thus work their will ! In Slavic tongue the mass they sing, Before God's table clustering ; Heretical their conduct bold, 
Such service in this land to hold.'

'Gainst Vitos this and more they said, And those of whom he was the head;

Their slanders had such force and strength, They drove them all away at length.

Abbot and brethren, meeting there,

Themselves to holy Procop's care

Commended, then with hearts of woe

Together did to Hung'ry go.

To others then was given their place,

To foreigners of German race.

These Germans Latinists were known,

And glad that convent made their own.

$\mathrm{O}$ faithless trickery of hell !

O human envy, sad to tell !

O faithless sland'rers that ye be,

The devil's emissaries ye!

The devil whispers to you now,

Ere long hell-fires will round you glow!

Who doth God's servants harm and wrong

Will perish from this world ere long.

E'en thus those sland'rers it befell,

Who in this world not long did dwell;

Procop their deed right ill did take,

And to them on this wise he spake.

They the first night to matins rose,

Each to the church in order goes,

There at the door did Procop stand,

And prophesied with upraised hand :

'Say, whence ye hither came to dwell?

What here hath been your bus'ness, tell ?

Yea, who hath hither sent you, say?

Who this abode hath given you, pray?

What seek ye, sland'rers, here in sight?

What claim ye in this place of right?'

The Germans stood with fixed gaze,

But not a word a German says ;

They all were awed in dire affright

At holy Procop's voice of might. 
In terror great they speed away,

But yet thus much in answer say :

'Bohemia's Prince, in order due,

His honourable council too,

Us in this convent here did plant,

And it to us till death did grant.'

When he a foreign language heard,

Procop continued thus his word:

'I warn you, by God's power and grace ;

Away, ye sland'rers, from this place!

If this ye shall neglect to do,

God's punishment will fall on you.'

This said, he vanish'd from their sight ;

The Germans service held aright,

No heed unto his warnings gave,

But thought them trick'ry of a knave.

A second night was well-nigh spent,

The brethren to their matins went;

The holy Procop came once more,

Stood in the church above the door,

Began to speak right angrily :

- Ye faithless Germans, tell me why

My warning thus with scorn ye treat.

Here is for you no dwelling meet.

Yea, ye have done right faithlessly,

Hence chased my sons by calumny.

Hence, sland'rers, quickly from this place!

I give you warning now by grace.'

Small heed thereto the Germans paid,

But turned to sport each word he said.

Till the third night he came in sight,

And did upon them show his might.

To them again he 'gan to say :

'Ye Germans, hearken now, I pray.

I have fulfill'd God's Holy Writ,*

But ye my word regard no whit.

* By two warnings-one between them and himself, and one in the church-he could now treat them as "heathen men and publicans" (Matt. xvii. 15-18). 
No place for you did I prepare,

For mine own sons I raised it fair ;

But, faithless sland'rers, not for you,

Ye are a vile Hungarian* crew !

The prince the convent gave, ye say;

But now I chase you hence away.

Good words could not your pride abate,

Sazava's home I'll make you hate.

Up! on your road no moment waste!

Take yourselves off to Prague with haste !'

This said, his hand a cudgel bore,

With which he thrash'd the Germans sore.

No word the Germans dared reply,

But each man foremost strove to fly;

No question ask'd they of the way,

But skipp'd along like goats at play."

They then went to the prince and told him to give the convent to whom he would-he would not get them to return thither, for they had been lucky to escape with their lives. "That Procop," said they, "who lies there, will not allow us to possess his territories; and no one whom he does not favour can hold that convent. We have been in fear of him; let every man beware of such punishment." The prince, hearing this, marvelled much, but did not think fit to repent and turn to God, "wherefore God shortened his days." Wratislaw succeeded him as Prince of Bohemia, sought out Vitos and the brethren, brought them back from Hungary, and replaced Vitos in his abbacy. "And thus was fulfilled the prophecy of the holy Procop."

However, Procop's saintly interference in support of the Slavonic ritual was only successful for a time. Discord broke out among the brethren, and in 1097 that ritual was entirely suppressed. But in 1394 the Emperor Charles IV. founded a Slavonic convent in the new town of Prague, with a view to the eventual reconciliation of the Greek and Roman Churches.

* "Hungarian" seems to have been a term of reproach in Bohemia, like "Dutchman" in England after the accession of William of Orange. 
448 TRANSACTIONS OF THE ROYAL HISTORICAL SOCIETY.

In this convent he placed monks from Dalmatia, Croatia, and other Slavonic countries, who made use of their own Slavonic ritual and the Glagolitic handwriting. Among other gifts, Charles presented the convent with the only relic of the old Bohemian Slavonic ritual still remaining, the Book of the Gospels, said to have been written by St Procop in the Cyrillic character with his own hand. This Slavonic codex, after various changes of fortune, obtained the high honour of becoming the book upon which the kings of France took their coronation oath at Rheims. 